\title{
Defining the Unemployment Determinants of the Post-Transition Central European EU Member Countries
}

\author{
Marija Bušelić \\ Juraj Dobrila University of Pula, Croatia \\ mbusel@unipu.hr \\ Jurica Bosna \\ University of Zadar, Croatia \\ jbosna@unizd.hr
}

\begin{abstract}
Aim of the research is to define unemployment determinants of the labor markets on the example of post-transition Central European EU member countries - Poland, Czech, Slovak, Hungary, Slovenia, and Croatia. The purpose of the paper is to point out the role and importance of studying the labor market unemployment determinants of the post-transition countries to provide a proposal for reducing unemployment. In this paper as independent macroeconomic variables have been analyzed gross domestic product, public debt, labor force participation rate and institutional variables like some fixed-term and part-time contracts and expenditures for active and passive labor market policies. An analysis of the labor market unemployment determinants for the Central European EU member countries has been conducted by econometric models of multiple linear regression for each country to determine whether there are differences in unemployment rates between countries within one panel. Results of the research show that in almost all countries, public debt as a macroeconomic variable has a significant impact on unemployment growth, while passive labor market policies of the institutional variables have the most significant impact on the level of unemployment.
\end{abstract}

Key Words: unemployment, determinants, labor market, post-transition

EU countries

JEL Classification: E24, J01

https://doi.org/10.26493/1854-6935.17.79-103

\section{Introduction}

Unemployment has been considered as an important issue, not only for the economy but also for society as a whole. In her paper Tomić (2013) states how due to its complexity, it's not easy to find an unambiguous explanation of the causes of unemployment. However, in a manner to find 
solutions for the suppression of unemployment, we must first investigate its causes.

Domonkos and Konig (2015) conclude that the cost of unemployment has been reflected in reduced state income due to lower tax rates, increased social benefits for the unemployed, lower amounts for pension and health insurance, major issuance for active labor market policies and reduced indirect tax revenues. In his paper Paul (2001) states that apart from the fact that unemployed persons do not receive income, they lose their skills during the time and their inactivity inevitably leads to social isolation. Boeri and Jimeno (2015) state that there is an increasing need for individual research of the European country's unemployment rates because of their differences and the specificities of institutions, interactions with macroeconomic shocks and economic policies of individual countries.

Aim of the research is to define unemployment determinants of the labor markets on the example of post-transition Central European EU member countries - Poland, Czech, Slovak, Hungary, Slovenia, and Croatia. These post-transitional countries of Central Europe were chosen because they were until the 199os planned economy and then entered the transition of the political and economic system. At the time of socialism, these countries did not have a market economy, especially the labor market. Due to the implementation of reforms and economy in all of the above mentioned Central European countries, unemployment increased in the nineties of the 2oth century. National labor markets marked high and long-term unemployment rates and extremely rigid labor legislation. New jobs in the private sector did not open at the same rate as workers lost their jobs. These inactivities have lasted (except in Croatia) until 2000 when the labor market of Central Europe stabilized. As they approached the date of their entry (2004), apart from Croatia (2013), they significantly modified the institutions and labor market policies according to the experience of the existing EU member states. Croatia did the same, but the changes were slower due to the Homeland War. All the countries with the liberalization of the European labor market have reduced their unemployment.

Analysis of the unemployment determinants for the selected countries will be conducted by using the econometric models of multiple linear regression for each country. To express the aim of the paper, the dependent variable in the models is the unemployment rate while macroeconomic and institutional variables that were not highly correlated in the 
model were considered as important for research. Since it was necessary to distinguish between countries within the same panel they do not look for common effects (as they are later explored) then this is what an exploratory question answered using regressions for individual countries and then tested how different parameters exist between countries the same panel is statistically significantly different.

The work structure with the introduction and conclusion deals with the following topics: The theoretical background of macroeconomic and institutional determinants of unemployment, chapter two deals with previous studies of macroeconomic and institutional variables of unemployment, in the third chapter Empirical analysis of unemployment determinants research on labor market and unemployment as well as on the variables affecting it, In the fourth chapter, the post-transition countries labor markets describe the labor markets of the observed countries in the posttransitional period, Research methodology is shown in the fifth chapter, in the sixth Results and discussion the results are presented and a review of the results obtained.

\section{The Theoretical Background of Macroeconomic and Institutional Determinants of Unemployment}

\section{MACROECONOMIC DETERMINANTS OF UNEMPLOYMENT}

This chapter presents an overview of important macroeconomic factors affecting the level and the movement of unemployment rates such as gross domestic product, public debt, direct foreign investment, labor productivity, and labor cost, labor force structure and labor force participation rates. The increase in economic activity, which affects the decline in unemployment, maybe due to increased investment and increased exports as a component of gross domestic product, which is the most common indicator of economic trends in the economy. Encinas-Ferrer and VillegasZermeño (2015) in their paper state that investments are a dynamic element of the gross domestic product that enables increased domestic production and increase employment.

Determining the relationship between real GDP growth and unemployment is important for policymakers to enable sustainable growth of living standards. Namely, real GDP growth allows for a reduction in unemployment, which by empirical analysis has been discovered by Bogdan et al. (2015), Umair and Ullah (2013), Ogueze and Uka Odim (2015) and many others. 
The high amount of government debt relative to the gross domestic product is particularly related to high levels of public spending and in the long run, it causes an increase in the unemployment rate. Public debt is a burden on future generations because it imposes a tax increase, which causes a further increase in unemployment and generates a vicious circle (Fedeli and Forte 2012).

The growing public debt obligations are an obstacle to the establishment of new development projects and thus prevent the reduction of unemployment. Therefore, public borrowing should only be justified in those situations where it is used for capital projects that can open up new jobs and positive financial indicators (Christiana Ogonna et al. 2016).

Mucuk and Tahir Demirsel (2013) investigated the relationship between foreign direct investment and unemployment, and they also concluded that in some countries direct foreign investment has a positive effect on unemployment while in other countries they have a negative impact. The relationship between direct foreign investment, employment, and unemployment differ significantly from country to country depending on the structure of the economy, the type of foreign direct investment received, and the different periods, whereby the structure of the economy can change significantly just like the types of foreign direct investment deadline.

Labor costs that include employee wages, benefits, taxes paid by employees and employers affect the employment decision and can contribute to unemployment if they are not aligned with labor productivity. Therefore, rising labor costs are not a problem if they are aligned with increasing labor productivity, which is considered a natural process of convergence of income (Kovtun et al. 2014).

Gallegati et al. (2014) state that in the long term there is a strong negative link between labor productivity and unemployment but also their strong positive relationship in the short term. In the medium term, new technology will reduce the workforce and increase the unemployment rate. However, in the long term, new technology (innovation process) to increase labor productivity contributes to the competitiveness of the company and the economy, which is affecting the reduction of the unemployment rate. Many countries are faced with changing the structure of the workforce and will face even more dramatic demographic changes in the coming years. From a theoretical perspective, reducing the number of working-active populations can reduce unemployment due to greater labor force outflows and a smaller number of the new workforce. 
Lee and Parasnis (2014) explored the ratio of labor force unemployment rates and labor force participation rates of developed and developing countries, while they concluded that increasing labor force participation rate causes an increase in the unemployment rate. However, it is particularly interesting and important to point out that the change in unemployment rates varies significantly between developed countries and developing countries. In developing countries, the increased labor force participation rate leads to a significant increase in the rate of unemployed people in contrast to developed countries that absorb more efficiently the increase in the number of workforces.

\section{INSTITUTIONAL DETERMINANTS OF UNEMPLOYMENT}

Cazes and Nesporova (2006) in their paper state that labor market institutions imply institutions and policies created for intervention in the labor market to improve the link between supply and demand for work, protect existing employees, enable workers to move to other jobs and help restore equality and equity for different social groups on the labor market.

Institutional labor market factors include employment protection regulations, active labor market policies, benefits for unemployed, labor taxation and collective bargaining (Pesliakaite 2016). The role and importance of legislative protection of employment has been intensively studied over the last decade due to modern labor market conditions, which means that the country through reform of legislative protection of employment attempts to increase employment and reduce unemployment through the efficient establishment of various legislative branches of employment protection (Aleksynska and Eberlein 2016).

Muller and Berger (2013) conclude that more rigid legal employment protection hurts the level and length of unemployment of observed countries, where women and young people are particularly vulnerable.

Strict legislative employment protection encourages companies to hire workers on fixed-term contracts (Di Porto, Elia, and Tealdi 2016).

The role and importance of the contract are increasing since they allow greater flexibility for employers and workers. The employer benefits from increased options for adjusting demand fluctuations for its products and can use temporary contracts as a cheaper way of gaining labor. For workers, they allow easier access to employment and the path to a contract for an indefinite period (Eurofound 2015).

It is interesting to point out that Cappellari, Dell'Aringa, and Leonardi (2012) have been concluded that the increased flexibility in the legislative 
protection of employment for temporary employment in practice results in the replacement of various types of temporary contracts where employment remains at the same level.

Active labor market policies include various instruments such as various incentives to work such as job opening incentives, job sharing, workplace change, training, or special assistance for disadvantaged groups. Active labor market policies are being designed and implemented to support mobility in the labor market and integrate unemployed and inactive persons into working people, with their content different from country to country.

Initially, policymakers considered that it is necessary to increase expenditure on active labor market policies to counteract unemployment. However, later experience of the countries revealed an interesting fact certain countries with relatively low labor market expenditures maintained a low unemployment rate, while other countries with aboveaverage spending on active labor market policies faced rising structural unemployment. Also, policymakers have neglected the fact that economic theory at the time emphasized, referring to the important interaction between the system of generous unemployment insurance, the size and the mix of active labor market policies, and the degree to which benefits for unemployed affect job search (Martin 2014).

Laporšek and Dolenc (2012) point out that the generous measures of the passive labor market policy are in a negative correlation with the transition from unemployment to employment. Research that has been conducted by Guzmán (2014) shows obvious evidence that passive labor market policies in the form of unemployment insurance have a significant impact on increasing the number of unemployed persons.

Establishing a minimum wage has caused several different views on its effectiveness. Barriers to the establishment of a minimum wage justify its introduction because it allows the income of workers to ensure their basic needs while the opponents of the establishment of the minimum wage point out its impact on the increase in the number of unemployed persons (Sika 2016).

However, many papers point out the negative impact of minimum wages for people with the lowest employment potential, and the conclusion that minimum wages and salaries only increase unemployment can't be avoided. Many authors dealing with labor market issues emphasize further potential negative aspects of relatively high established minimum wages that are mostly associated with the inability to hire low- 
productivity people, which thus remain unattractive to work (Bejaković 2015).

Labor tax burden significantly affects the level of personal consumption and employment. Although labor taxation has limited power to address economic imbalances, it nevertheless contributes to the establishment of labor market balance, which points to the importance of observing its impact on labor market efficiency (Šimović and Deskar-Škrbić 2015).

The high tax wedge, hence the high tax burden on wages, is directly influenced by high unemployment. The increase in labor taxes reduces the average duration of employment in the formal sector, significantly reduces the number of employees in the formal sector and significantly increases the informal sector and the readiness of the workforce to accept the job in the informal sector.

From the research conducted by Dolenc and Laporšek (2010) has been finding out that reducing tax wage contributes to increasing employment, decreasing unemployment and consequently leads to greater productivity and competitiveness.

\section{Empirical Analysis of Unemployment Determinants}

In his paper Scarpetta (1996) clearly points out how it is impossible to set up a comprehensive model that can fully satisfy and show the movement of unemployment, given that unemployment is influenced by numerous institutional, cultural and historical facts which determine the efficiency of the labor market and is not possible to include them all in the model. Purnama-Trimurti and Komalasari (2014) state that authors most commonly, when analyzing unemployment determinants, in models include institutional and macroeconomic variables to analyze the issue comprehensively. Analysis of the unemployment determinants starts with the identification of the potential institutional factors which could have an impact on the labor market efficiency, whose theoretical strength derives from different theories of unemployment and ends with an analysis of more important macroeconomic factors. Also, certain models analyze unemployment determinants from micro or macro aspects, labor supply or demand and the development of certain countries.

The impact of institutional and macroeconomic factors on unemployment has been reflected in the failure of the labor market - its adjustment to the general economic situation of the observed country. The first attitude of the Organization for European Economic Co-operation (OECD) 
and International Monetary Fund (IMF) was that labor market failures are the result of its inflexibility, which stems mainly from market institutions and that systematic institutional deregulation is needed to reduce unemployment. Point of view that the institutional structure causes the rigidity of the labor market is widely accepted by policymakers, whereby the claim in question stands at the base of unemployment theories that establish a link between labor market institutions and long-term unemployment (Pesliakaite 2011).

Some of the authors emphasize that mostly institutional factors of the labor market can explain unemployment trends, while others analyze macroeconomic variables. However, they have concluded that macroeconomic stability has a significant impact on unemployment. Labor market institutions have a different impact on unemployment due to different economic opportunities and labor market policies (Sturn 2011).

In her paper, Jandrić (2013) states that many economists considered that the unemployment in Europe would be solved by removing labor market regulations, protecting laws, reduction of unemployment benefits, reducing the power of syndicates, and by decentralization of the wage determination process. That was a message of an OECD job study from 1994. that emphasized the significance of wage flexibility, the danger of employment protection legislation (E PL) and the need for unemployment benefits limitation. Also, the author furtherly emphasizes how the IMF in its study from 2003. points out that causes of unemployment can be found in labor market institutions that are the main cause of high unemployment rates according to the attitudes of many experts. Accordingly, countries with high unemployment rates have been constantly encouraged to undertake comprehensive structural reforms that would reduce the rigidity of the labor market (high unemployment benefits, employment protection, minimum wages), improve the right-setting mechanism and encourage an adequate wage tax system.

Blanchard and Wolfers (2000) state how labor market institutions do not affect so directly unemployment rate but their negative impact is most likely to be reflected when macroeconomic shocks occur in the economy, and then institutions accelerate a negative effect on unemployment. They also suggest that a more favorable macroeconomic environment and the improvement of labor market institutions should have a significant impact on reducing unemployment. Nickell et al. (2002) are the initiators of the approach of studying unemployment through institutional determinants and macroeconomic stability. 
'The general impact of individual institutional variables on labor market efficiency is still not sufficiently clarified because the effects of certain institutional arrangements are not the same for different labor market groups. A large number of recent studies don't give a clear answer to the question of whether an inflexible labor market directly causes high unemployment rates, nor does empirical research uniquely confirm liberalorthodox attitudes. There is no consensus about the impact of the labor market institutions on the unemployment rate, primarily about the statistical significance of some institutional variables, and in some cases about the sign of impact' (Jandrić 2013, 69).

Based on analyzed literature, Jandrić (2013) concludes how certain countries that have a more rigid labor market in the long term achieve better performance than some countries with far more flexible labor markets. In their paper Tasci and Zenker (2013) state how countries with highly flexible institutions and labor market policies have been characterized by greater fluctuations in the unemployment rate during economic cycles, as opposed to countries with more rigid labor market features.

According to the Guidelines for the Implementation of Active Employment Policy Measures (2013), a comprehensive approach for solving the problem of unemployment is needed by linking the institutions responsible for creating policies for education, economy, work, and regional development as well as social partners and civil society organization. Without social dialogue and wider dialogue with the interested public, it's not possible to achieve solutions that will be truly effective and sustainable in the long run.

Also, Zubović and Domazet (2012) consider that in spite of the extraordinary efforts for improving labor market policies, a significant increase in employment will not be possible without the overall increase in economic activity. Mrnjavac (2013) emphasizes how the height and dynamics of the unemployment rates in Europe reflect economic trends while changes in the functioning of the labor market did not have a significant impact on unemployment. Therefore, growth policy allows the creation of new jobs as a basic prerequisite for reducing the number of unemployed.

Although the issue of unemployment is important for economic theory and society as a whole, we can conclude from the analyzed literature that there is no clear and unique answer to the question about the correct specification of the labor market unemployment determinants and that there is no general conclusion about the determinants of unemployment 
which certainly shows the complexity of the unemployment. According to the analyzed literature, it can be concluded that the determinants of unemployment can be divided into macroeconomic, institutional and other factors.

\section{Characteristics of the Observed Post-Transition Countries Labor Markets}

During the early transition periods in the nineties of the 2oth century, unemployment in the countries of Central Europe increased due to rapid labor market reforms. New jobs in the private sector had not been open at the same rate as workers lost their jobs (Boeri and Terrell 2002). National labor markets marked high and long-term unemployment rates and extremely rigid labor legislation (Nesporova, 2000). These changes also marked growing inactivity until 2000 when the Central European labor market started to stabilize (European Commission 2008).

Cazes and Nesporova (2003) indicate that increased labor market flexibility in the Central European countries didn't contribute to the improvement of the labor market performance but has hurt employment, redistribution and labor productivity. However, Pesliakaite (2016) concluded by exploring the determinants of unemployment in the long run for the Central European countries, that the institutional structure causes labor market flexibility, which has an impact on the unemployment as well as indicators of macroeconomic stability. Therefore, the author emphasizes that structural reforms and increased labor market flexibility are needed for lowering unemployment rates in Central European countries.

Cazes and Nesporova (2006) point out that the countries of Central Europe have significantly modified the institutions and labor market policies in a manner to respond to the challenges of labor recruitment. As the date of entry into the European Union approached, Central European countries accelerated the adaptation of labor market institutions and policies according to the experience of existing member states. Scutariu (2015) states that it is a clear positive effect of increasing employment while the pace of the falling unemployment rate has been accelerated with the accession of Central European countries into the European Union. In her paper, Kunovac (2013) states that in the period from 2008. to 2013. has been obvious a strong trend in reducing legal protection of employment in most Central European countries, primarily in the form of individual layoffs, regular employment contracts, while temporary employment protection has been slightly strengthened. 
Labor demand has a strong impact on the movement of unemployment, while there is a significant link between the unemployment and employment rate in the case of Poland labor market suggesting that reduction of the unemployment rate is not the cause of increased labor inactivity (Strawinski 2008). Qiddah (2013) states that Poland has one of the strongest European economies. Membership in the European Union has helped Poland to attract more financial resources and increase employability while Ambrosetti - The European House (2016) points out that Poland has one of the most flexible labor markets in the European Union.

When we look at the unemployment of Poland from the regional point of view, we come to the knowledge that there are very different local unemployment determinants. Generally speaking, differences in local unemployment rates are mainly influenced by local demographic factors, levels of education and structure of individual sectors as opposed to labor demand (Cizkowicz, Kowalczuk, and Rzonca 2014).

Accession to the European Union in 2004 led to numerous changes in the Czech labor market, the most significant of which is the increase in flexibility (Knězáčková and Volejníková 2014). Based on the labor flow of unemployment from unemployment to employment, we can conclude that the Czech is lagging in creating new jobs. The significantly low capacity of the Czech labor market in absorption, especially low educated and senior labor, points to the presence of structural disparities between the above categories of labor with the needs of the labor market. It is, therefore, necessary to establish an efficient active labor market policy, to provide more flexible forms of employment and to introduce stronger measures against the gray economy (Flek and Mysikova 2015).

In his paper Kwiatkiewicz (2010) states that the general character of the Czech labor market is a low level of unemployment but whereas a more detailed analysis of the labor market indicates huge regional inequalities of unemployment rates, whereby it is important to highlight gender differences and the lack of appropriate skills (Pavelka and Roster 2013).

Slovakia's labor market has some similar characteristics with other post-transition EU member countries. For example, the labor force participation rate is slightly below the European Union average, while the inactivity of the older population (over 55) and women are particularly pronounced, unlike other European Union countries. Regarding labor market institutions, we can conclude that the Slovak Republic has a flexible labor market. Also, it has the lowest amounts of unemployment 
benefits and social benefits in general (European Commission 2014).

Long term unemployment is the main problem on the Slovakian labor market while main causes of unemployment in Slovakian labor market are poor structure of the economy, exclusion of low-skilled population, tax burdens on labor income, low skill levels and declining trends in the demand for manual workers, impact of minimum wage on Slovakian labor market, high level of regulations and bureaucracy, and low mobility of Slovakian labor force (Zeman 2018).

In the period from 2008 to 2013, Hungary's unemployment gradually declined as a result of public employment - active labor market measures, which accounted for almost half of the newly opened jobs and required significant fiscal expenditures (Adam 2014). However, in his paper, Tvrdon (2016) states that since 2013 Hungary's structural unemployment has increased due to internal economic problems in the area of public finances and the growth of the state debt.

The highly qualified and productive labor force is an important characteristic of the Hungarian labor market what is the reason why foreign investors invest in Hungary (Horvath 2011). The Hungarian labor market is characterized by a moderate unemployment rate, a relatively low rate of labor force participation and flexible labor market institutions (European Economic Advisory Group 2012). Low labor force participation rates and employment rates are characteristics of the Hungarian labor market (Galgoczi 2010).

The issues facing the Slovenian labor market are the results of labor market institutions that were not adequately prepared for the changes in the post-transition period. The Republic of Slovenia has a complex system of employment and dismissals where employers are reluctant to employ a new workforce. It is worth to point out that the employers hire workforce mainly on the fixed term contract that indicates insecurity of job retention (Joyce 2014). The expenditures for active labor market policies have a negative and statistically significant effect on the unemployment rate, whereas the expenditures for passive labor market policies have a positive and statistically significant effect on the unemployment rate (Južnik Rotar 2018, 55).

Low labor market activity rates and employment rates are indicators that probably best illustrate the weaknesses of the Croatian labor market, while a relatively high unemployment rate confirms problems with creating a sufficient number of jobs even in the conditions of low labor supply. The current situation on the labor market of the Republic of Croa- 
tia can be seen as a result of three key factors: cyclical low demand for labor, structurally high unemployment, inadequate labor supply, and institutional (regulatory) rigidity that enhances adverse effects of cyclic and structural factors (Nestić 2015, 43-44).

\section{Research Methodology}

An analysis of labor market unemployment determinants in post-transition EU countries has been conducted by using econometric models of multiple linear regression for each country. An econometric model unemployment rate represents dependent variable while independent variables are macroeconomic (real gross domestic product, public debt expressed as a percentage of the GDP and labor force participation rate) and institutional variables (number or fixed and part-time contracts and expenditures for the active and passive labor market policies).

The index of the legal protection of employees is not taken into account because there are no uniform indicators for all the years to be analyzed.

Quarterly data have been used for the period from 2000 to 2015. The reason why the analysis started in 2000 was that these countries were planners until 1990. Croats and Slovenes were part of Socialist Yugoslavia, while Czech, Slovak, Polish, and Hungarian were influenced by Soviet politics. With the beginning of the 1990 s entering the transition (political, legal and economic system). How transition has introduced the transformation of ownership (from planning to market). Unemployment in Central European countries increased due to rapid labor market reforms (introduced by the transition). At the same time, there was very rigid working legislation that was understandable due to the previous way of life. These negative changes lasted until the year 2000 when the Central European labor market stabilized except Croatia. Precisely from this analysis was started with the 2000 year. For the models of the observed countries data were collected from the Eurostat database while data for active and passive labor market policies were found from the oECD database on an annual basis, which was transformed into quarterly data by the frequency distribution method because they are flow variables.

Gross domestic product is an indicator of the economic activity and demand for the labor force, public debt is an indicator of the government's ability to cope with high rates of unemployment, by the labor force participation rate we can see how the activity of the workforce affects the movement of unemployment, fixed-term contracts as well as the number of part-time workers are indicators of labor market flexibility, active labor 


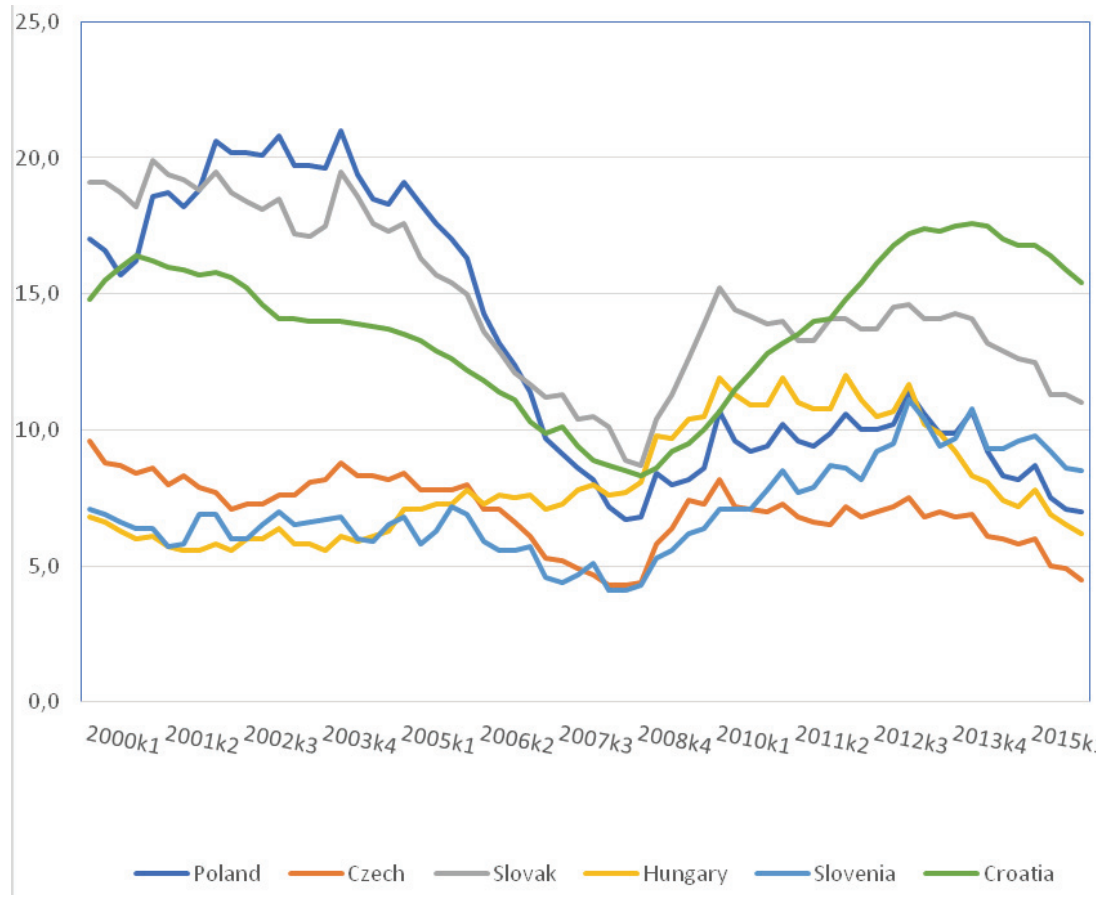

FIGURE 1 Movements of the Unemployment Rates

market policies represent effectiveness in combating unemployment and ultimately passive labor market policy that are potential source of labor force passivity on the labor market in finding employment.

Highly correlated variables (import, export, foreign direct investment, interest rate, inflation) were omitted from the analysis. All variables from the model have been seasonally adjusted by ARIMA X11 methodology in a manner to avoid links between variables due to common seasonal movements rather than some of their direct links. Also, all variables are expressed in the natural logarithm, which allows us to have models with constant elasticity as most macroeconomic theoretical models assume. Moreover, these log-log models allow a simpler interpretation of the obtained coefficients since it is about partial coefficients of elasticity. The models have included three broken trends by the dummy variables in a manner to get stationary variables.

From figure 1 we can see, based on the unemployment movement that the countries in the analyzed period went through three phases: before the crisis, the crisis and after the crisis. 


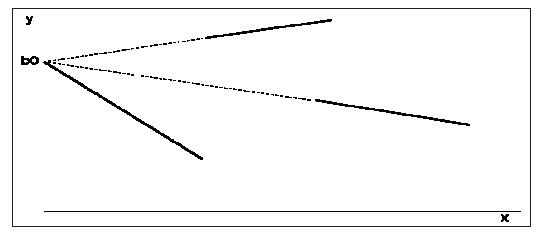

FIGURE 2 Ordinate Line Section

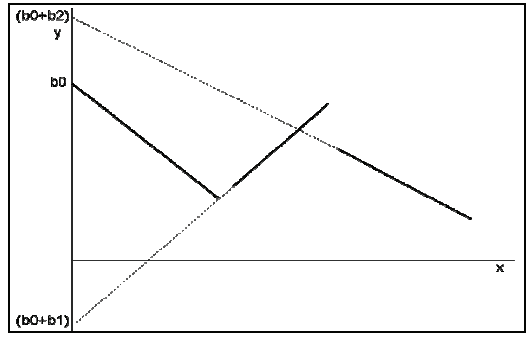

FIGURE 3 Different Line Slides on Ordinate

It has been taken period of the crises from the fourth quarter of the 2008 until the fourth quarter of the 2013 due to consistency and comparability of all individual models. To obtain breaks in models, the following dummy variables were included:

$$
\begin{aligned}
& \text { before_trend }=\left\{\begin{array}{l}
t \text { for } 2008 \mathrm{q} 4-2013 \mathrm{q} 4 \\
o \text { for other periods }
\end{array} \quad t=1,2,3, \ldots,\right. \\
& \text { crisis_trend }=\left\{\begin{array}{l}
t \text { for } 2008 \mathrm{q} 4-2013 \mathrm{q} 4 \\
\text { o for other periods }
\end{array} \quad t=1,2,3, \ldots,\right. \\
& \text { after_trend }=\left\{\begin{array}{l}
t \text { for } 2008 \mathrm{q} 4-2013 \mathrm{q} 4 \\
o \text { for other periods }
\end{array} \quad t=1,2,3, \ldots,\right.
\end{aligned}
$$

to get three different trends of unemployment depending on the period and two more constant members where it is important not to limit the directions in order to have the same odds on the ordinate (figure 2).

Lines should be allowed to get different sections by additional dummy variables that will allow shifts to vary depending on the observation period. Additional dummy variables are the following:

$$
\begin{aligned}
& \text { crisis_con }=\left\{\begin{array}{l}
t \text { for } 2008 \mathrm{q} 4-2013 \mathrm{q} 4 \\
o \text { for other periods }
\end{array} \quad t=1,2,3, \ldots,\right. \\
& \text { after_con }=\left\{\begin{array}{l}
t \text { for } 2008 \mathrm{q} 4-2013 \mathrm{q} 4 \\
0 \text { for other periods }
\end{array} \quad t=1,2,3, \ldots,\right.
\end{aligned}
$$

by which we get a different line slides on ordinate (figure 3).

Parameter linked to crisis_con is b1 and parameter linked to after_con is 
TABLE 1 Results of the Regressions

\begin{tabular}{|c|c|c|c|c|c|c|}
\hline & Poland & Czech & Slovakia & Hungary & Slovenia & Croatia \\
\hline GDP & $\begin{array}{l}0.164 \\
(1.42)\end{array}$ & $\begin{array}{l}-0.488 \\
(-1.27)\end{array}$ & $\begin{array}{r}-0.760 \\
(-1.33)\end{array}$ & $\begin{array}{l}-0.623^{* * *} \\
(-3.71)\end{array}$ & $\begin{array}{l}-0.795^{* * *} \\
(-5.304)\end{array}$ & $\begin{array}{l}0.506 \\
(1.61)\end{array}$ \\
\hline PUD & $\begin{array}{l}1.223^{* * *} \\
(6.35)\end{array}$ & $\begin{array}{l}0.344^{*} \\
(2.46)\end{array}$ & $\begin{array}{l}1.106^{\star * *} \\
(4.41)\end{array}$ & $\begin{array}{l}0.485 \\
(1.57)\end{array}$ & $\begin{array}{l}0.483^{* * *} \\
(12.27)\end{array}$ & $\begin{array}{l}0.508^{* *} \\
(4.24)\end{array}$ \\
\hline LFPR & $\begin{array}{l}4.697^{* * *} \\
(3.71)\end{array}$ & $\begin{array}{l}4.579 \\
(1.37)\end{array}$ & $\begin{array}{l}-2.532 \\
(-1.22)\end{array}$ & $\begin{array}{l}-0.509 \\
(-0.34)\end{array}$ & $\begin{array}{r}-0.738 \\
(-0.4571)\end{array}$ & $\begin{array}{l}-1.375^{* *} \\
(-3.19)\end{array}$ \\
\hline FTC & $\begin{array}{l}0.313^{\star *} \\
(3.30)\end{array}$ & $\begin{array}{r}0.317 \\
(1.02)\end{array}$ & $\begin{array}{r}-0.0439 \\
(-0.43)\end{array}$ & $\begin{array}{l}-0.271 \\
(-1.96)\end{array}$ & $\begin{array}{l}0.378^{\star} \\
(1.815)\end{array}$ & $\begin{array}{r}0.0809 \\
(1.32)\end{array}$ \\
\hline PTC & $\begin{array}{l}0.638^{* *} \\
(2.96)\end{array}$ & $\begin{array}{l}-0.869^{*} \\
(-2.09)\end{array}$ & $\begin{array}{l}0.156 \\
(1.17)\end{array}$ & $\begin{array}{r}-0.0982 \\
(-0.77)\end{array}$ & $\begin{array}{r}-0.098 \\
(-0.5995)\end{array}$ & $\begin{array}{l}-0.0112 \\
(-0.24)\end{array}$ \\
\hline ALMP & $\begin{array}{r}0.0314 \\
(0.71)\end{array}$ & $\begin{array}{l}0.633^{* * *} \\
(5.74)\end{array}$ & $\begin{array}{r}0.0838 \\
(1.26)\end{array}$ & $\begin{array}{r}0.0794 \\
(1.54)\end{array}$ & $\begin{array}{r}0.0595 \\
(1.040)\end{array}$ & $\begin{array}{r}-0.0208 \\
(-0.80)\end{array}$ \\
\hline PLMP & $\begin{array}{l}0.422^{* * *} \\
(3.56)\end{array}$ & $\begin{array}{l}0.348^{\star} \\
(2.34)\end{array}$ & $\begin{array}{l}-0.0611 \\
(-0.61)\end{array}$ & $\begin{array}{l}0.339^{* * *} \\
(3.86)\end{array}$ & $\begin{array}{l}\text { * } 0.2157^{* * *} \\
(3.587)\end{array}$ & $\begin{array}{l}0.270^{* * x} \\
(4.65)\end{array}$ \\
\hline crisis_trend & $\begin{array}{r}-0.0101 \\
(-1.68)\end{array}$ & $\begin{array}{r}0.000517 \\
(0.04)\end{array}$ & $\begin{array}{r}-0.0194 \\
(-1.79)\end{array}$ & $\begin{array}{l}0.0192^{* *} \\
(3.37)\end{array}$ & $\begin{array}{r}0.0187 \\
(2.63)\end{array}$ & $\begin{array}{l}0.0191^{* *} \\
(3.25)\end{array}$ \\
\hline cons & $\begin{array}{l}28.65^{* * *} \\
(-4.99)\end{array}$ & $\begin{array}{l}-18.69 \\
(-1.09)\end{array}$ & $\begin{array}{r}17.54 \\
(1.72)\end{array}$ & $\begin{array}{r}5.832 \\
(0.89)\end{array}$ & $\begin{array}{r}8.288 \\
(1.518)\end{array}$ & $\begin{array}{r}0.895 \\
(0.24)\end{array}$ \\
\hline$R^{2}$ & 0.992 & 0.904 & 0.938 & 0.974 & 0.928 & 0.986 \\
\hline
\end{tabular}

NOTES GDP - gross domestic product (in bn of euros, in real terms), PUD - public debt (\% of GDP), LFPR - labor force participation rate, FTC - fixed term contract (number of fixed term contracts), P TC - part time contract (number of part time contracts), ALMP - active labor market policies (in mil of euros), PLMP - passive labor market policies (in mil of euros); $t$-statistics are in brackets below the coefficients while probabilities are in brackets below the $t$-statistics; significance levels are denoted as: ${ }^{*}$ significant at $5 \%$, ${ }^{* *}$ significant at $1 \%,{ }^{* * *}$ significant at $0,1 \%$.

b2 from figure 3, while coefficients of slope direction are dummy variables - before_trend, crisis_trend and after_trend.

\section{Results and Discussion}

Regression results on the example of Poland show how public debt, labor force participation rate, fixed-term contracts, part-time contracts, and passive labor market policies have a significant and positive impact on the movement of the unemployment rate. The greatest impact on the movement of the unemployment rate has a labor force participation rate. One percent increase in labor force participation rate increases unemployment for $4.70 \%$ (table 1 ). 
Employment rates are less than the labor force inflow rates in Central European countries, which is particularly evident on the Polish example. Poland has reached a high degree of labor market flexibility and needs further strong economic growth to combat unemployment while public debt and increasing labor force inflow represent major obstacles.

On the example of Slovak Republic, from all variables of the regression model, only public debt had a significant impact on the movement of the unemployment rate - one percent increase of public debt increases unemployment rate by $1.11 \%$.

Huge structural unemployment of Slovak Republic shows that unemployment is the cause of a mistaken institutional framework rather than short-term fluctuations such as economic cycles. Incorrectly established institutional framework implies inadequate institutional incentives in the area of taxation and social benefits, labor market rules, education system, ect. Therefore, in order to significantly reduce unemployment, it is necessary to bring and establish effective institutional changes with no attention being paid solely to economic growth (Goliaš 2014). Also, in her paper Martincova (2013) states that Slovak public debt has particularly large impact on the movements of unemployment.

Based on the labor flow from unemployment to employment, we can conclude that the Czech Republic is lagging behind in creating new jobs. The significantly low capacity of the Czech labor market in absorption, particularly low educated and senior work force, indicates the presence of structural mismatches of the above mentioned categories of labor with the needs of the labor market. It is therefore necessary to establish an effective active labor market policy to provide more flexible forms of employment and to introduce stronger measures against the gray economy (Flek and Mysikova 2015).

Czech has increased labor market flexiblity according to the regression results, especially part time contracts that decrease unemployment. On the example of Czech Republic, it can bee seen that public debt (0.34), part time contracts ( -0.87 ), active labor market policies (o.63) and pasive labor market policies (0.35) have significant impact on the movement of the unemployment rate. One percent increase of public debt increases unemployment rate for $0.34 \%$, one percent increase of part time contracts decreases unemployment for $0.87 \%$, one percent increase of active labor market policies increases unemployment for $0.63 \%$ and one percent increase of pasive labor market policies increases unemployment for $0.35 \%$.

Significant impact on Hungarian unemployment rate had GDP and 
passive labor market policies. GDP had a negative impact (-0.62) while the passive labor market policies had a positive impact on the movement of the unemployment rate (o.34). Other variables from the model were not significant which means that in the observed period they did not have impact on the movement of the unemployment rate.

Hungarian labor market has a highly qualified and productive labor force that is a significant feature of the hungarian labor market and is also important determinant for foreign direct investments. Also, it is important to point out how foreign direct investments have significant positive role on the hungarian economic development and for opening new jobs (Horvath 2011). Hungary indicates economic situation that has a large space for increasing labor market flexibility which will in the future require further strong economic growth.

On the example of Slovenia GDP has significant impact on reduction of unemployment rate (-0.79) while public debt (o.48), fixed term contracts (0.38) and passive labor market policies (o.21) had significant positive impact on unemployment. In his paper Joyce (2014) state how fixed term contracts in a short period of time decrease unemployment while employers are not willing to employ workforce on indefinite period of time for the rigidity of the labor market.

Significant determinants of unemployment of the Republic of Croatia in the observed period are public debt (0.58), labor force participation rate $(-1.37)$ and passive labor market policies $(0.27)$. One percent increase of public debt increased unemployment for $0.58 \%$, labor force participation rate decreased unemployment for $1.37 \%$ and pasive labor market policies increased unemployment for $0.27 \%$. Therefore, the strongest impact on unemployment of the Republic of Croatia had labor force participation rate while its one percent increase led to decrease of unemployment for $1.37 \%$. Labor force participation rate represents the ratio of the labor force and the total population which indicates the workforce activity while the increase in the rate of labor participation may be also due to the emigration of labor force.

The Republic of Croatia needs to establish more efficient active and passive labor market policies, work on reduction of the public debt and set up measures and policies that will have impact in reducing unemployment rates and the outflow of working-age population. Higher labor demand than the size of the workforce certainly leads to a reduction of the unemployment rate. Therefore, recent research in the analysis of unemployment determinants include the employment finding rates and the 
job loss rates. In the models of this paper coefficients of determination for each regression are higher than $90 \%$ which indicates a strong connection between the dependent and independent variables and how independent variables describe well movements of the dependent variables.

\section{Conclusion}

Unemployment as an indicator of the economic and social condition is a result of different macroeconomic, institutional and other important factors that points out its complexity. Based on the results of the regressions, it can be concluded that each observed country has different determinants of unemployment. Despite the countries having similar features, they differ to a smaller or greater extent which is reflected in their labor market.

So at the beginning of the crisis in 2008, the Czech had an unemployment rate of $4.4 \%$, Croatia $8.6 \%$, Hungary $7.8 \%$, Poland $7.1 \%$, Slovenia $4.4 \%$ and Slovakia 9.6\%. According to the level of unemployment, the crisis in these countries has lasted for a long time because the unemployment rate for 2012 in the Czech was 7.0\%, Croatia 15.8\%, Hungary 11.0\%, Poland 10.1\%, Slovenia 4, 4\% and Slovakia 9.6\%. In 2015, unemployment rates were lower than in 2012 in the Czech by $5.1 \%$, Hungary by $6.8 \%$, Poland by $7.5 \%$ and Slovakia by $11.5 \%$, although Poland and Slovakia still have a higher unemployment rate in 2008 . Slovenia has a $9 \%$ unemployment rate in 2015 and Croatia $16.1 \%$. These are twice the higher rates compared to 2008 , indicating that the economies have not fully recovered from the crisis and especially Croatia whose GDP was negative from 2009 to 2015 . The analysis of the unemployment rate after 2015 for the countries surveyed shows that they are all the Czech decreased to $2.2 \%$, Croatia at $8.5 \%$, Hungary to $3.7 \%$, Poland to $3.9 \%$, Slovenia to $5.1 \%$ and Slovakia to $6.5 \%$. The unemployment rate in Croatia significantly decreased, partly due to the growth of the gross domestic product, but also due to the opening up of European labor markets (all except Austria). Thus, Croatians have the possibility of free employment and departure to European countries. This has also affected the size of the supply of labor and the need for greater imports of seasonal workers.

According to this research, it is obvious how public debt as a macroeconomic variable in most countries has the strongest positive impact on unemployment. The reason is that the public debt as a share of the GDP leads to the extrusion of investments, the reduction of exports and debt servicing, and thus the reduction of economic growth. Certainly, these 
negative consequences reflect significantly on the level of unemployment. From the institutional variables have been observed the significant impact of the passive labor market policy on unemployment. This policy primarily refers to the material protection of unemployed persons in the form of unemployment benefits and mostly do not stimulate the unemployed workforce in the job-seeking process. Although their amount was significantly higher at the beginning of the transition period in all observed countries, as the number of unemployed increases, this benefit decreases and is regulated differently in each country. However, these benefits serve unemployed persons as a security measure rather than a temporary form of financial support until finding a job. As a result, this institutional variable has a significant impact on the level of unemployment.

Labor market rigidity has been often used as a cause of unemployment, but labor market flexibility can't solve the long-term unemployment problem because its measures are only effective in short-term unemployment suppression. Therefore, further efforts in the labor markets need to be directed towards a more effective establishment of the concept of flexicurity, one of the strategic goals of the European Union. In a EU document has been emphasized the necessity of pursuing policies aimed at achieving 'full employment,' 'improving quality' and 'work productivity.' Considering that this document in the field of employment relations highlights the need for flexibility and security because the flexicurity model emphasizes job security on employability security (Bušelić 2017). Activities for increasing flexibility and safety on the labor market require the presence of effective active employment policies, lifelong learning, labor mobility policies and an adequate social security system to provide adequate support to employees and the unemployed.

Although flexicurity policy should encourage economically efficient and social fair labor market by reducing unemployment and increasing employment, in conditions where there is no economic growth and new investments, previously mentioned effects can't be expected (Bušelić 2017, 142).

Work is important for the academic community, policymakers, experts, students of economics and management, as well as for the wider public interested in the labor market. It also provides important insight into further design and development of labor market middle-European countries.

Since this work resulted from the analysis of Central European coun- 
tries using multiple linear regression for each country, the results for each country were obtained based on which they could compare and differentiate between them. The common features of the observed countries, ie macroeconomic or institutional variables, are also identified in the paper as the causes of their unemployment. Therefore, for future research, it is proposed to expand independent variables (both macroeconomic and institutional) as well as expand the number of countries (comparisons of Baltic or South European) with more recent data using panel analysis.

\section{References}

Adam, Z. 2014. Fight Against Unemployment: The case of Hungary. Budapest: Institute for Economic Research.

Aleksynska, M., and F. Eberlein. 2016. 'Coverage of Employment Protection Legislation.' IZA Journal of Labor Policy 5 (17): 1-20.

Ambrosetti - The European House. 2016. 'Poland: A Sustainable Transformation to a Leading Economy.' Position paper, Cernobbio. http:// docplayer.net/41097927-Poland-a-sustainable-transformation-to-a -leading-economy.html

Bejaković, P. 2015. 'A Revision of the Shadow Economy in Croatia: Causes and Effects.' Economic Research 28 (1): 422-40.

Blanchard, O., and J. Wolfers. 200o. 'The Role of Shocks and Institutions in the Rise of European Unemployment: The Aggregate Evidence.' The Economic Journal 110 (462): 1-33.

Boeri, T., and F. Jimeno. 2014. 'The Unbearable Divergence of Unemployment in Europe.' Banco de Espana Working Paper 1534, Banco de Espana, Madrid.

Boeri, T., and K. Terrell. 2002. 'Institutional Determinants of Labor Reallocation in Transition.' Journal of Economic Perspectives 16 (1): 51-76.

Bogdan W., D. Boniecki, E. Labaye, T. Marciniak, and M. Nowacki. 2015. Poland 2025: Europe's New Growth Engine. N.p.: McKinsey \& Company.

Bušelić, M. 2017. Suvremeno tržište rada. Pula: Sveučilište Jurja Dobrile u Puli.

Cappellari, L., C. Dell'Aringa, and M. Leonardi. 2012. 'Temporary Employment in Italy.' Cesifo DICE Report, ifo Institut, Leibniz.

Cazes, S., and A. Nesporova. 2003. Labour Markets in Transition: Balancing Flexibility and Security in Central and Eastern Europe. Geneva: ILo.

Cazes, S., and A. Nesporova. 2006. 'Combining Flexibility and Security for Employment and Decent Work in the Western Balkans.' South-East Europe Review for Labour and Social Affairs 9 (2): 7-24.

Christiana Ogonna, I., O. Stephen Idenyi, A. Charity Ifeyinwa, and N. Udochukwu Gabriel. 2016. 'The Implications of Rising Public Debt on 
Unemployment in Nigeria: An Auto Regressive Distributed Lag Approach.' Asian Research Journal of Arts \& Social Sciences 1 (1): 1-15.

Cizkowicz, P., M. Kowalczuk, and A. Rzonca. 2014. 'Heterogeneous Determinants of Local Unemployment in Poland.' Narodowy Bank Polski Working Paper 188, Economic Institute, Warsaw.

Di Porto, E., L. Elia, and C. Tealdi. 2016. 'Informal Work in a Flexible Labour Market.' Oxford Economic Papers 69 (1): 143-64.

Dolenc, P., and S. Laporšek. 2010. 'Tax Wedge on Labour and Its Effect on Employment Growth in the European Union.' Prague Economic Papers 4:344-58.

Domonkos, T., and B. Konig. 2015. 'Estimation of the Cost of Unemployment in Slovak Republic.' Politicka Ekonomie 63 (4): 498-516.

Encinas-Ferrer, C., and E. Villegas-Zermeño. 2015. 'Foreign Direct Investment and Gross Domestic Product Growth.' Procedia: Economics and Finance 24:198-207.

Eurofound. 2015. Recent Developments in Temporary Employment: Employment Growth, Wages and Transitions. Luxembourg: Publications Office of the European Union.

European Commission. 2014. 'Path Dependence and the Persistence of Unemployment in the Slovak Republic.' EFCIN Country Focus 11 (3): 1-9.

European Economic Advisory Group. 2012. 'The Hungarian Crisis.' The EEAG Report on the European Economy, Center for Economic Studies, Munich.

Fedeli S., and F. Forte. 2012. 'Public Debt and Unemployment Growth: The Need for Fiscal and Monetary Rules. Evidence from oECD Countries (1980-2009).' Economia Politica 29 (3): 399-427.

Flek, V., and M. Mysikova. 2015. 'Uneployment Dynamics in Central Europe: A Labour Flow Approach.' Prague Economic Papers 1:73-87.

- 2015. 'Youth Labour Flows and Unemployment in Great Recession: Comparing Spain and the Czech Republic.' Review of Economic Perspectives 15 (2): 179-95.

Galgoczi, B. 2013. 'A Continuous Shrinking of the Unemployment Benefit System.' In Unemployment Benefit Systems in Europe and North America: Reforms and Crisis, edited by F. Lefresne, 281-92. Brussels: Etui.

Gallegati, M., M. Gallegati, J. Ramsey, and W. Semmler. 2014. 'Does Productivity Affect Unempoyment? A Time Frequency Analysis for the us.' In Wavelet Applications in Economics and Finance, edited by M. Gallegati and W. Semmler, 23-46. Dynamic Modeling and Econometrics in Economics and Finance 20. Cham: Springer.

Goliaš, P. 2014. 'How to Decrease Unemployment in Slovakia.' http://www .ineko.sk/file_download/788/How+to+decrease+unemployment+in + Slovakia.pdf 
Guzmán, G. 2014. 'How Effective Are Active Employment Policies to Reduce Unemployment in EU Countries?' Atlantic Review of Economics 2:1-15.

Horvath, J. 2011. 'Evaluation of the Hungarian Labor Market in Terms of a Shortage of Skilled Labor in Germany.' In Eu Strategy for the Danube Region: Perspectives for the Future, edited by I. Tarrósi and S. Milford, 149-60. Pécs: IDM.

Jandrić, M. S. 2013. 'Fleksibilnost i sigurnost na tržištu rada i uticaj na nezaposlenost u zemljama u tranziciji. $\mathrm{PhD}$ dissertation, University of Belgrade.

Joyce, B. 2014. 'The Struggle of Trade Unions and Slovenian Labor Market Reform.' Slovenia: Challenges and Opportunities, 47-58. Bethlehem, PA: Lehigh University.

Južnik Rotar, L. 2018. 'The Effects of Expenditures for Labour Market Policy on Unemployment Rate.' Business Systems Research 9 (1): 55-64.

Knězáčková, R., and J. Volejníková. 2014. 'The Labour Market in the Czech Republic after Accession to the Eu. In The 8th International Days of Statistics and Economics: Conference Proceedings, 687-97. Libuše Macáková: Melandrium.

Kovtun, D., A. Meyer Cirkel, Z. Murgasova, D. Smith, and S. Tambunlertchai. 2014. 'Boosting Job Growth in the Western Balkans.' I MF Working Paper 14/16. International Monetary Fund, Washington, DC.

Kunovac, M. 2013. 'Employment Protection Legislation in Croatia.' Financial Theory and Practice 38 (2): 139-72.

Kwiatkiewicz, A. 2010. 'The Implementation of Flexicurity and the Role of the Social Partners. Joint Study of the European Social Partners.' http://erc-online.eu/wp-content/uploads/2014/04/2011-00557-E.pdf

Laporšek, S., and P. Dolenc. 2012. 'Do Flexicurity Policies Affect Labour Market Outcomes? An Analysis of Eu Countries.' Revija za socijalnu politiku 19 (2): 107-29.

Lee, G. H. Y., and J. Parasnis. 2014. 'Discouraged Workers in Developed Countries and Added Workers in Developing Countries? Unemployment Rate and Labour Force Participation.' Economic Modelling 41:908.

Martin, J. P. 2014. 'Activation and Active Labour Market Policies in OECD Countries: Stylized Facts and Evidence on Their Effectiveness.' IZ A Policy Paper 84, Institute for the Study of Labor, Bonn.

Martincova, M. 2013. 'Impact of the Global Crisis on Labor Markets and Unemployment in Slovak Republic.' European Scientific Journal 1:16o5.

Mrnjavac, Ž. 2013. 'Active Labour Market Policy: Fighting a Dragon with a Toothpick.' Zagrebački ekonomski forum (7): 39-53. 
Mucuk, M., and M. Tahir Demirsel. 2013. 'The Effect of Foreign Direct Investments on Unemployment: Evidence from Panel Data for Seven Developing Countries.' Journal of Business Economics and Finance 2 (3): 53-66.

Muller, L., and D. P. Berger. 2013. 'The Impact of a Country's Employment Protection Legislation on Its Economic Prosperity'. International Journal of Humanities and Social Science 3 (12): 1-13.

Nestić, D. 2015. Ključni problemi hrvatskog tržišta rada: projekt "Zaposlimo Hrvatsku«. Zagreb: Hrvatska gospodarska komora.

Nickell, S., L. Nunziata, W. Ochel, and G. Quintini. 2002. The Beveridge Curve, Unemployment and Wages in the OECD from the 1960s to the 1990s. London: Centre for Economic Performance, London School of Economics and Political Science.

Ogueze, V. C., and O. Uka Odim. 2015. 'The Cost of Unemployment and Its Effects on GDP Growth in Nigeria.' World Applied Sciences Journal 33 (1): 86-95.

Paul, S. 2001. 'A Welfare Loss Measure of Unemployment with an Empirical Illustration.' The Manchester School 69 (2): 148-63.

Pavelka, T., and T. Loster. 2013. 'Changes in Regional Unemployment Rates in the Czech Republic during Economic Cycle.' Intellectual Economics 7 (4): 510-22.

Pesliakaite, J. 2011. 'Determinants of Unemployment in CE E-10 Economies: The Role of Labour Market Institutions and the Macroeconomic Environment in 2002-2012.' http://mpra.ub.uni-muenchen.de/66041

Pesliakaite, J. 2016. 'Determinants of Unemployment in Central and Eastern European Economies.' Ekonomska teorija i praksa 1:30-49.

Purnama-Trimurti, C., and Y. Komalasari. 2014. 'Determinants of Unemployment: Empirical Evidences from 7 Province in Indonesia.' Scientific Research Journal 2 (8): 5-9.

Qiddah, D. 2013. 'Country Profile: Republic of Poland.' https://www.sidf.gov .sa/en/MediaCenter/ResearchandStudies/

ExportInformationCountryProfileCurrent/2013-CP-Poland.pdf

Scarpetta, S. 1996. 'Assessing the Role of Labour Market Policies and Institutional Settings on Unemployment: A Cross Country Study'. OECD Economic Studies 26:43-98.

Scutariu, A. L. 2015. 'An Analysis of Unemployment in the Countries of Eastern and Central Europe in the Context of EU' The USV Annals of Economics and Public Administration 15 (Special): 80-86.

Sika, P. 2016. 'The Relationship of the Minimum Wage and Unemployment in the Slovak Republic.' Paper presented at the 16th International Scientific Conference on Economic and Social Development: The Legal Challenges of Modern World, Split, 1-2 September. 
Strawinski, P. 2008. 'What Drives the Unemployment Rate in Poland' Munich Personal RePEc Archive 11372, Munich.

Sturn, S. 2011. 'Labour Market Regimes and Unemployment in OECD Countries.' Macroeconomic Policy Institute, Düsseldorf.

Šimović, H., and M. Deskar-Škrbić. 2015. 'Efficency of Value Added Tax in Croatia.' In Proceedings of the 9th International Conference European Entrepreneurship Forum 2015: Efficiency in the Private and the Public Sector, 144-51. Prague: Newton College.

Tomić, I. 2013. 'Essays on the Labour Market in a Post-Transition Economy: The Case of Croatia.' PhD dissertation, University of Ljubljana.

Tvrdon, M. 2016. 'Decomposition of Unemployment: The Case of the Visegrad Group Countries.' Ekonomie 9 (1): 4-16.

Umair, M., and R. Ullah. 2013. 'Impact of GDP and Inflation on Unemployment Rate: A Study of Pakistan Economy in 2000-2010.' International Review of Management and Business Research 2 (2): 388-400.

Zeman, M. 2018., 'Unemployment in Slovakia between 1998 and 2016: One of the Systemic Problems of the National Economy'. Ecoforum 7 (1): 1-8.

Zubović, J., and I. Domazet. 2012. New Challenges in Changing Labour Markets. Belgrade: Institute of Economic Science.

This paper is published under the terms of the Attribution-

NonCommercial-NoDerivatives 4.o International (CC B Y-NC-ND 4.0)

License (http://creativecommons.org/licenses/by-nc-nd/4.o/). 